\title{
The Response of Muskmelon Growth and Development to Microclimate Modification by Shelterbelts
}

\author{
Dongsheng Zhang ${ }^{1}$, James R. Brandle ${ }^{1}$, Laurie Hodges ${ }^{2}$, \\ Entin Daningsih ${ }^{2}$, and Kenneth G. Hubbard ${ }^{1}$ \\ University of Nebraska, Lincoln, NE 68583
}

Additional index words. wind stress, temperature, phenology, leaf area, dry weight, relative growth rate, cantaloupe, Cucumis melo

\begin{abstract}
The relationships between shelterbelt (tree windbreak)-induced microclimate and muskmelon (Cucumis melo L.) growth and development were investigated at the Univ. of Nebraska-Lincoln Agricultural Research and Development Center near Mead, Nebr., during the 1992 and 1993 growing seasons. Wind speed, wind direction, air and soil temperatures, relative humidity, and soil moisture were monitored in both sheltered and nonsheltered areas. Plant growth parameters (plant height, vine length, plant dry weight, and leaf area) were measured at various stages of development. Shelterbelts provided improved growing conditions for muskmelon transplants. Direct wind damage and duration of higher wind speeds were reduced $47 \%$ to $56 \%$ in sheltered areas. Air temperatures in sheltered areas were slightly higher during daytime and slightly lower at night, and significantly so early in the growing season. Relative humidity was increased significantly in sheltered areas in 1992 and, while higher in 1993, the difference was nonsignificant. Soil moisture content was not affected significantly by wind protection. Sheltered plants exhibited earlier development and faster growth. The first female flower appeared 2 days earlier in sheltered areas in both years. The first fruit set, as indicated by fruit swelling and retention on the vine, occurred 6 days earlier and matured 5 and 6 days earlier in sheltered areas in 1992 and 1993, respectively. Leaf areas and dry-matter accumulation of sheltered plants were greater than those of exposed plants. The shoot relative growth rate of sheltered plants increased earlier in the growing season, but decreased slightly later in the growing season. The earlier development and faster growth of sheltered plants were related mainly to the reduction of wind speed, higher total accumulated air temperatures during the daylight hours (sum of daily average daytime air temperatures based on hourly averages), and higher soil temperature in sheltered areas. Total yields were not affected significantly in either year; however, early yields were significantly greater in sheltered areas in 1993. If earlier maturity and increased yield are possible in large sheltered fields, this practice would provide an economic benefit to producers.
\end{abstract}

Shelterbelts modify microclimates and thereby affect crop growth and development (Aase and Siddoway, 1974; Baldwin, 1988; Barker et al., 1989; Black and Aase, 1988; Brandle et al., 1984; Frank et al., 1974; Kort, 1988). In general, the beneficial effects of shelterbelts on crop growth, development, and yield have been attributed to the prevention of wind damage because of reduced wind speed and soil abrasion (Grace, 1977; Wei et al., 1987), and to improved soil water regimes and

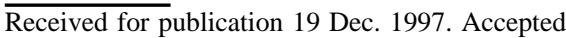
for publication 8 May 1998. Published as Univ. of Nebraska Agricultural Research Division Journal Series Paper No. 12100. This project was supported by funds from the McIntire Stennis Cooperative Research Program. Mention of a trade name or proprietary product does not constitute a guarantee or warranty of the product by the Univ. of Nebraska. The cost of publishing this paper was defrayed in part by the payment of page charges. Under postal regulations, this paper therefore must be hereby marked advertisement solely to indicate this fact. ${ }^{1}$ School of Natural Resource Sciences.

${ }^{2}$ Dept. of Horticulture.
}

plant water status (Frank et al., 1974; Grace, 1977; Rosenberg et al., 1983). Other effects are attributed to higher daytime air and soil temperatures, as well as lower air temperature at night in the sheltered zone (Marshall, 1967; Rosenberg et al., 1983). Changes in canopy morphology of sheltered plants also may contribute to higher yield (Ogbuehi and Brandle, 1982).

However, the effects of shelterbelts on microclimates and the response of vegetable crops to microclimate modification vary with crop species and from season to season (Bagley and Gowen, 1960; Baldwin, 1988; Harrison and Chrimes, 1988). According to Baldwin (1988), vegetable crops are highly susceptible to wind and wind abrasion. Studies on runner bean (Harrison and Chrimes, 1988) and tomato (Bagley and Gowen, 1960) indicated higher yield, higher quality, and greater economic gain because of reductions in wind speed in sheltered areas.

The objectives of this study were to determine the effects of shelterbelts on muskmelon growth and development, and to relate any such effects to microclimatic factors.
Study sites and soil information. The study was conducted at the shelterbelt research area at the Univ. of Nebraska-Lincoln Agricultural Research and Development Center near Mead (lat. $41^{\circ} 29^{\prime} \mathrm{N}$; long. 96 $6^{\circ} 25^{\prime} ; 354 \mathrm{~m}$ above sea level) during the 1992 and 1993 growing seasons. Two treatments were used: sheltered from wind vs. exposed to wind. Shelter was provided by mature shelterbelt systems established in 1966 (Brandle et al., 1984). Each plot was $225 \mathrm{~m}^{2}$ (1992) or $190 \mathrm{~m}^{2}$ (1993) and was divided into two subplots by a guard row in both years. There were eight treatment rows and three guard rows in each plot. The sheltered plots were located between one and two shelterbelt heights $(\mathrm{H})$ north of the shelterbelts. For each treatment, three replicated plots were used in 1992 and four in 1993. Separate shelterbelt systems were used for each sheltered treatment plot. Additional details on shelterbelt design are discussed below.

The soil was an Aksarben silty clay loam (Fine, Smectitic, mesic Typic Arguidoll). Soil samples were taken from the top $20 \mathrm{~cm}$ of soil before transplanting, and analyzed for available N, P, K, and pH levels. Based on soil test results, $\mathrm{N}$ was applied at $89.6 \mathrm{~kg} \cdot \mathrm{ha}^{-1}$ in 1992 and $67.2 \mathrm{~kg} \cdot \mathrm{ha}^{-1}$ in 1993 to bring all soils to $110 \mathrm{~kg} \cdot \mathrm{ha}^{-1}$ (Knott et al., 1988). No potassium or phosphorous was needed. No irrigation was applied after plant establishment.

Shelterbelt characteristics. The prevailing winds in eastern Nebraska during the summer months (May-September) are from the south (Lawson et al., 1977); consequently, eastwest-oriented shelterbelts were considered as the primary belts in this study. In 1993, the shelterbelts were composed of two mixed rows of green ash (Fraxinus pennsylvanica L.), eastern red cedar (Juniperus virginiana L.), and Austrian pine (Pinus nigra Arnold). Average height of the shelterbelt systems increased from 11.9 to $12.5 \mathrm{~m}$ over the 2-year study. In 1992, a shelterbelt system composed of two rows of alternating eastern red cedar and Scotch pine ( $P$. sylvestris L.) with a height of $9.1 \mathrm{~m}$ was used in addition to those described for 1993. The width of all shelterbelt systems was $8 \mathrm{~m}$ with an approximate summer density of $60 \%$.

Meteorological measurements. All microclimatic data were recorded on CR10 automatic data loggers (Campbell Scientific, Inc., Logan, Utah) located in the center of each plot. Wind speeds were measured with 3-cup anemometers (model 12102; R.M.Young, Traverse City, Mich.) at $50 \mathrm{~cm}$ and $2 \mathrm{~m}$ aboveground. Wind direction was measured with Gill microvanes (model 12302; R.M. Young) at a height of $2 \mathrm{~m}$. Air temperature and humidity were measured $45 \mathrm{~cm}$ aboveground using a temperature and relative humidity probe (model XN217; Campbell Scientific). Soil temperature was measured at a depth of $7.5 \mathrm{~cm}$ with averaging soil thermocouple probes (model TCAV; Campbell Scientific) in 1992 and with copper-constantan thermocouples in 1993. All parameters were sampled every minute and hourly averages were recorded. 
Daily mean values were calculated from hourly averages. Day/night splits were adjusted through the season to reflect changes in sunrise and sunset. Average wind speed for a given time interval was calculated based on hourly average wind speeds. The percent reduction in average hourly wind speed was calculated by dividing the average hourly value in the exposed areas by that in the sheltered areas. Soil moisture of the top $20 \mathrm{~cm}$ was determined weekly by the gravimetric method.

Plant material. Muskmelon, cv. Hiline, seeds coated with captan ( $N$ - $N$-tricloromethylthio-4-cyclohexane-1,2-dicarboximide) and thiram (tetramethylthiuram disulfide) were provided by Asgrow Seed Co., Kalamazoo, Mich. 'Hiline' is a nonsutured western shipper melon with an average fruit weight of $1.59 \mathrm{~kg}$. It has good disease resistance and vine vigor.

Plant establishment. Seeds were sown on 28 Apr. in both 1992 and 1993 in 2.54-cm cells (Growing Systems 73 Cell Tray; Growing Systems, Inc., Milwaukee) containing a mixture of 1 peatmoss: 1 vermiculite : 1 perlite (by volume). Fertilizer (540 mg. $\mathrm{L}^{-1} \mathrm{~N} ; 2700$ $\mathrm{mg} \cdot \mathrm{L}^{-1} \mathrm{P} ; 900 \mathrm{mg} \cdot \mathrm{L}^{-1} \mathrm{~K}$ ) was applied once a week. Plants in the single-leaf stage were transferred to a lath house and watered prior to transplanting. Plants were transplanted by hand $30 \mathrm{~cm}$ apart into $10-\mathrm{cm}$-high raised beds oriented perpendicular to the shelterbelts on 20 May 1992 and 3 June 1993. Over the course of the study, plants were thinned to a final spacing of $240 \mathrm{~cm}$. Rows were $2.7 \mathrm{~m}$ apart in 1992 and $1.8 \mathrm{~m}$ apart in 1993 to allow for subplots within the space available. Beehives were located within $0.4 \mathrm{~km}$ of the plots throughout the 2-year study.

Plant growth and development. To maintain relatively consistent spacing between plants and minimize damage to remaining plants during sampling, each subplot was systematically divided into groups from which random samples could be drawn. These removals were part of the thinning process. Spacing was increased to $60 \mathrm{~cm}$ between individual plants within the row by flowering and $240 \mathrm{~cm}$ by fruit set.

The dates of first open male and female flower, fruit set, and maturity were recorded. For the first 2 weeks following the appearance of flowers, the number of male and female flowers were counted daily in each subplot. In subsequent weeks, they were counted only on those plants sampled for growth measurements. Plant height and vine lengths were measured in the field prior to harvesting for growth measurements. Plants were cut at ground level and taken indoors, where the leaves, stems including petiole, male and female flowers, and fruits were separated and counted. Leaf area was measured with a model Li-3000 area meter (LI-COR, Lincoln, Nebr.) and an accessory transparent belt conveyer. Dry weight of each plant part was determined by drying to a constant weight at $60^{\circ} \mathrm{C}$. Shoot relative growth rate was calculated as $(1 / \mathrm{w})(\mathrm{dw} /$ $\mathrm{dt}$ ), where w, dw, and dt were shoot dry weight, shoot dry weight increment, and time increment in days from transplanting, respectively.
Yield. Mature fruit were harvested three times a week. On each harvest date, all fruit at "half slip" or "full slip" were collected, counted, and weighed. sis. A randomized complete-block design was used with three replications in 1992 and four replications in 1993. Analysis of variance was performed using the general linear model (GLM) of SAS (SAS Institute, 1985) to test for differences in plant height, vine length, leaf area, and plant dry weight. The analysis of variance showed no significant difference between subplot data, so analyses and interpretations were made on full plot data. Regression equations were calculated on plant growth parameters and microclimate variables to determine the best fit (highest significant $R^{2}$ ).

\section{Results and Discussion}

Wind speed. Average wind speed reduction in sheltered areas during the growing seasons (48\% reduction in 1992 and $57 \%$ reduction in 1993) was dependent on wind direction and exposed wind speed. The reduction was greatest early in the growing season when winds were from the south, southeast, or southwest and wind speeds were higher. From the viewpoint of protecting different agricultural crops, effective protection by shelterbelts
Experimental design and statistical analy-

depends not only on the amount of wind speed reduction but also on the frequency of high wind speed. A comparison of wind speeds between sheltered and nonsheltered areas indicated that total hours of wind speeds between 2 and $4 \mathrm{~m} \cdot \mathrm{s}^{-1}$ and winds $>4 \mathrm{~m} \cdot \mathrm{s}^{-1}$ were significantly fewer in sheltered areas (Table $1)$.

Air temperature and soil temperature. Maximum air and soil temperatures in the sheltered areas were higher early in the growing season during both years. However, differences in daily mean or minimum temperatures between sheltered and exposed areas were not consistently significant (Table 2). The inconsistency of the effects of shelter on air and soil temperatures during the whole growing season may have been due, in part, to the variability in wind direction, radiation load, advective or nonadvective conditions (Rosenberg et al., 1983), soil moisture, and plant cover (Marshall, 1967).

Soil moisture and humidity. Shelters did not affect soil moisture content during either growing season. Seasonal mean soil water content in sheltered and exposed areas was $17.4 \%$ and $17.6 \%(P=0.294)$ in 1992 , and $26.3 \%$ and $25.6 \%(P=0.357)$ in 1993 , respectively. Mean soil water content over the first month after transplanting in 1992 was $16.7 \%$ and $17.8 \%(P=0.152)$ in sheltered and ex-

Table 1. Effect of shelters on duration of exposure to various wind speeds measured $50 \mathrm{~cm}$ aboveground from muskmelon transplanting to first mature fruit harvest in 1992 and 1993.

\begin{tabular}{|c|c|c|c|c|}
\hline \multirow{3}{*}{$\begin{array}{l}\text { Average hourly } \\
\text { wind speed }(u) \mathrm{m} \cdot \mathrm{s}^{-1}\end{array}$} & \multicolumn{4}{|c|}{ Total time $(\mathrm{h})^{\mathrm{z}}$} \\
\hline & \multicolumn{2}{|c|}{1992} & \multicolumn{2}{|c|}{1993} \\
\hline & Exposed & Sheltered & Exposed & Sheltered \\
\hline $0<u \leq 2$ & $1286 \pm 3$ & $1905 \pm 6$ & $1389 \pm 3$ & $2066 \pm 5$ \\
\hline $2<u \leq 4$ & $726 \pm 2$ & $155 \pm 1$ & $674 \pm 3$ & $86 \pm 2$ \\
\hline$u>4$ & $141 \pm 1$ & $3 \pm 0$ & $92 \pm 1$ & $3 \pm 0$ \\
\hline Total & 2063 & 2063 & 2155 & 2115 \\
\hline
\end{tabular}

${ }^{\mathrm{z}}$ Mean total hours \pm SE for three replications in 1992, and four replications in 1993. Times are accumulated hours based on hourly averages.

Table 2. Average daily maximum, minimum, and mean air and soil temperatures ${ }^{\mathrm{z}}$ during the first $30 \mathrm{~d}$ of the growing season and the entire growing season (transplant date to first harvest) in sheltered and exposed areas planted with muskmelon in 1992 and 1993.

\begin{tabular}{|c|c|c|c|c|}
\hline & \multicolumn{2}{|c|}{ First 30 days of the season } & \multicolumn{2}{|c|}{ Entire season } \\
\hline & Exposed & Sheltered & Exposed & Sheltered \\
\hline & \multicolumn{4}{|c|}{1992} \\
\hline \multicolumn{5}{|c|}{ Air temperature $\left({ }^{\circ} \mathrm{C}\right)$} \\
\hline Maximum & $25.4 \pm 0.1$ & $26.4 \pm 0.1^{*}$ & $27.2 \pm 0.1$ & $28.4 \pm 0.1^{*}$ \\
\hline Mean & $18.4 \pm 0.1$ & $18.6 \pm 0.1$ & $20.1 \pm 0.1$ & $20.5 \pm 0.1$ \\
\hline Minimum & $12.4 \pm 0.0$ & $11.8 \pm 0.1$ & $13.9 \pm 0.1$ & $13.8 \pm 0.1$ \\
\hline \multicolumn{5}{|c|}{ Soil temperature $\left({ }^{\circ} \mathrm{C}\right)$} \\
\hline Maximum & $27.9 \pm 0.1$ & $29.5 \pm 0.2^{*}$ & $29.3 \pm 0.2$ & $29.6 \pm 0.2$ \\
\hline Mean & $20.1 \pm 0.1$ & $21.0 \pm 0.1$ & $21.4 \pm 0.1$ & $21.6 \pm 0.1$ \\
\hline \multirow[t]{2}{*}{ Minimum } & $12.3 \pm 0.0$ & $12.2 \pm 0.0$ & $13.8 \pm 0.0$ & $13.1 \pm 0.0^{*}$ \\
\hline & \multicolumn{4}{|c|}{1993} \\
\hline \multicolumn{5}{|c|}{ Air temperature $\left({ }^{\circ} \mathrm{C}\right)$} \\
\hline Maximum & $26.8 \pm 0.2$ & $27.9 \pm 0.2^{*}$ & $28.6 \pm 0.1$ & $28.7 \pm 0.1$ \\
\hline Mean & $20.4 \pm 0.1$ & $20.5 \pm 0.1$ & $21.4 \pm 0.1$ & $21.0 \pm 0.1$ \\
\hline Minimum & $14.8 \pm 0.1$ & $13.4 \pm 0.1^{*}$ & $16.8 \pm 0.1$ & $15.6 \pm 0.1^{*}$ \\
\hline \multicolumn{5}{|c|}{ Soil temperature $\left({ }^{\circ} \mathrm{C}\right)$} \\
\hline Maximum & $25.5 \pm 0.1$ & $26.2 \pm 0.1^{*}$ & $25.5 \pm 0.2$ & $26.1 \pm 0.1$ \\
\hline Mean & $21.4 \pm 0.1$ & $22.4 \pm 0.1$ & $22.3 \pm 0.1$ & $23.1 \pm 0.2$ \\
\hline Minimum & $17.2 \pm 0.0$ & $18.6 \pm 0.1^{*}$ & $19.1 \pm 0.1$ & $20.0 \pm 0.1$ \\
\hline
\end{tabular}

${ }^{\mathrm{z}}$ Mean \pm SE for three replications in 1992, and four replications in 1993.

*Significantly different from the value for exposed area at $P \leq 0.05$. 


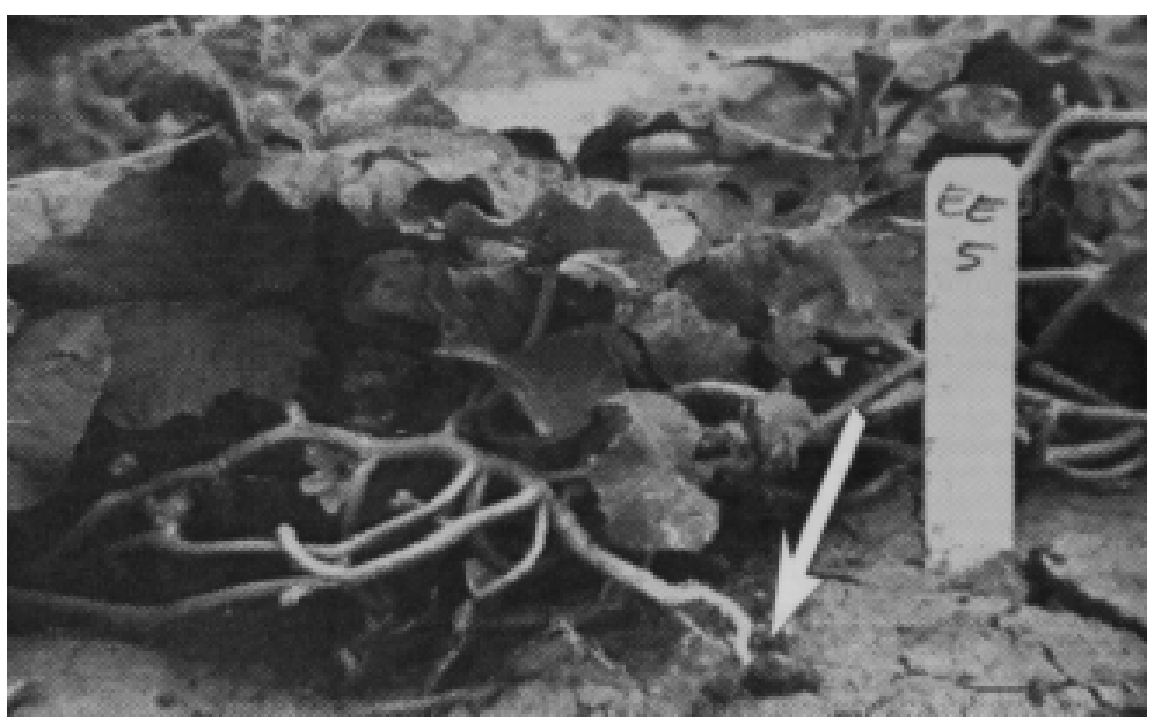

Fig. 1. Exposed muskmelon plants following wind stress conditions on 9 July 1993 . Note root pulled from the soil (arrow). posed areas, respectively, perhaps reflecting the greater water use by the more vigorous sheltered plants. Mean soil water content over the first month after transplanting in 1993 was $25.5 \%$ and $25.1 \%(P=0.786)$ in sheltered and exposed areas, respectively. Seasonal mean relative humidity in sheltered and exposed areas was $74.8 \%$ and $68.6 \%(P=0.056)$ in 1992 , and $81.1 \%$ and $77.5 \%(P=0.2691)$ in 1993, respectively.

Muskmelon growth and development. Sheltered plants exhibited earlier development. The first female flower reached anthesis $2 \mathrm{~d}$ earlier $(P=0.043)$ in sheltered areas both years. The results were similar to previous findings for tomato (Baldwin, 1988) and soybean (Ogbuehi and Brandle, 1982). The first fruit set occurred 7 and $6 \mathrm{~d}$ earlier $(P \leq 0.001)$ and the first fruit matured 5 and $7 \mathrm{~d}$ earlier $(P$ $\leq 0.001)$ in sheltered areas in 1992 and 1993 . Mechanical wind damage was observed in exposed areas on 9 July 1993. Average hourly

Table 3. Effects of wind protection on muskmelon plant height, vine length, leaf area, dry weight, and shoot relative growth rate (RGR) during the 1992 and 1993 growing seasons.

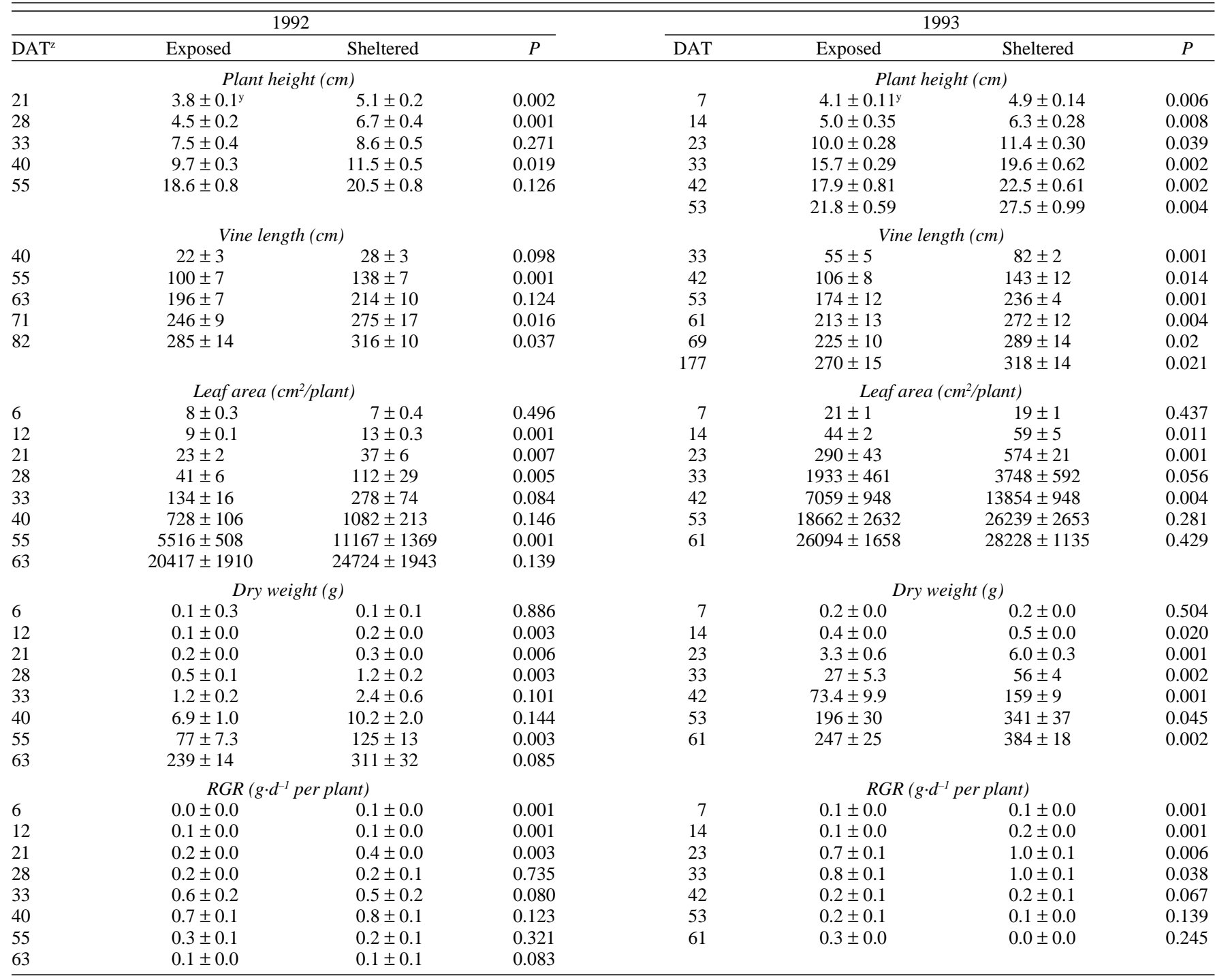

${ }^{2}$ Days after transplanting.

y Mean \pm sE for three replications in 1992 and four replications in 1993. 


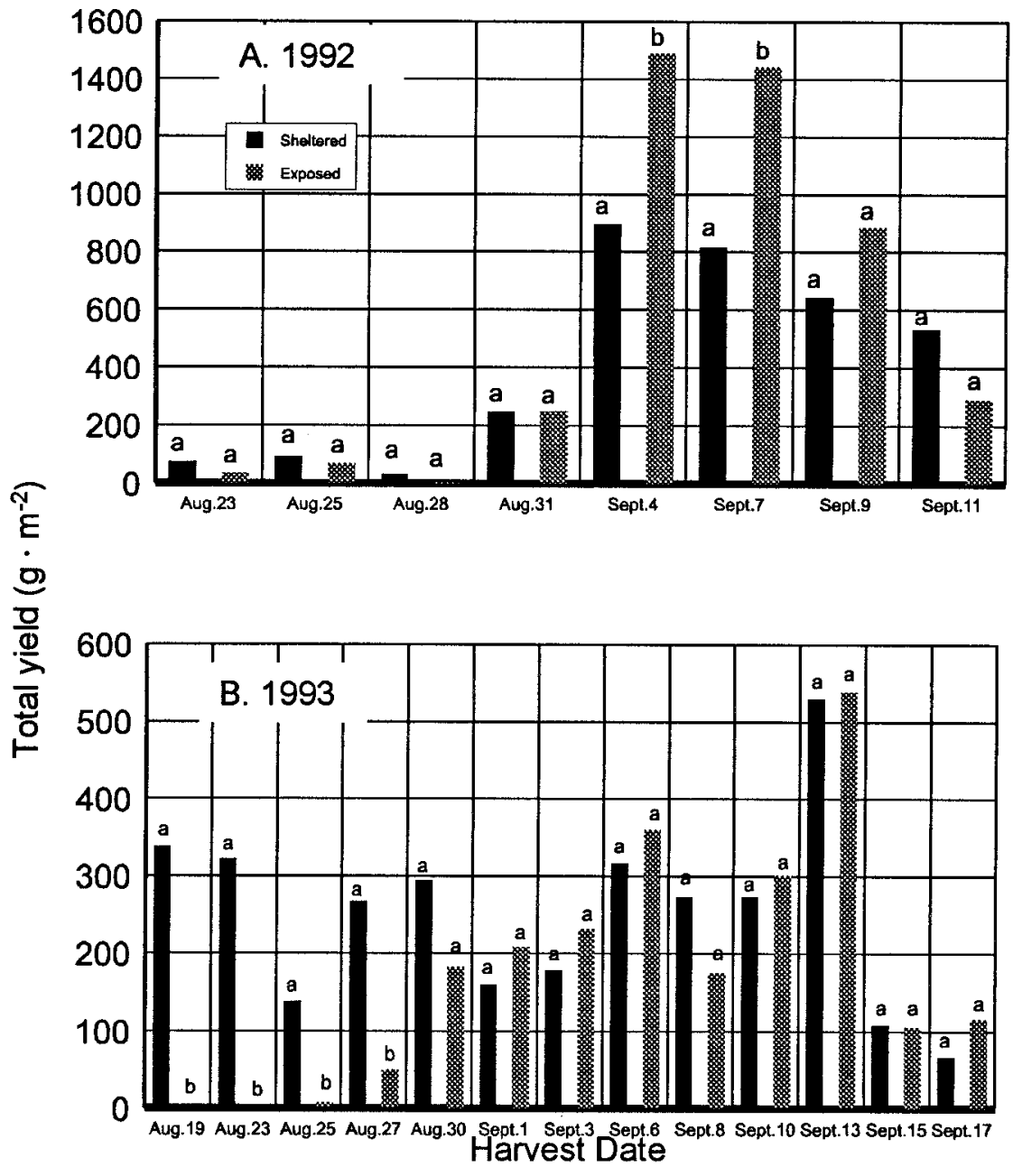

Fig. 2. The relationship between of accumulated daytime heat units and dry-matter accumulation in sheltered vs. exposed muskmelon plants.

Table 4. Regression of muskmelon relative shoot growth rate (RGR in $\mathrm{g} \cdot \mathrm{d}^{-1}$ per plant) on mean daytime air temperature $\left({ }^{\circ} \mathrm{C}\right)$ and mean daytime soil temperature $\left({ }^{\circ} \mathrm{C}\right)$ during the first $30 \mathrm{~d}$ after transplanting in sheltered (wind protected) or exposed plots in 1992 and 1993.

\begin{tabular}{|c|c|c|c|c|}
\hline Year & Treatment & RGR $=$ & $R^{2}$ & $P$ \\
\hline \multirow[t]{4}{*}{1992} & Exposed & $0.00178\left(1.26605^{\mathrm{b} \text { air }}\right)^{\mathrm{z}}$ & 0.76 & 0.0056 \\
\hline & & $0.00334\left(1.37155^{\text {b soil }}\right)^{\mathrm{y}}$ & 0.88 & 0.0034 \\
\hline & Sheltered & $0.01120\left(1.17016^{\mathrm{b} \text { air }}\right)$ & 0.52 & 0.0089 \\
\hline & & $0.00347\left(1.23255^{\mathrm{b} \text { soil }}\right)$ & 0.64 & 0.0131 \\
\hline \multirow[t]{4}{*}{1993} & Exposed & $0.00003\left(1.52153^{\mathrm{b}}\right.$ air $)$ & 0.95 & 0.0001 \\
\hline & & $0.00001\left(1.52897^{\mathrm{b} s o i l}\right)$ & 0.92 & 0.0005 \\
\hline & Sheltered & $0.00006\left(1.50178^{\mathrm{b} \text { air }}\right)$ & 0.95 & 0.0001 \\
\hline & & $0.00002\left(1.66065^{\text {b soil }}\right)$ & 0.79 & 0.0073 \\
\hline
\end{tabular}

${ }^{2 \mathrm{~b}}$ air $=$ Mean daytime air temperature $\left({ }^{\circ} \mathrm{C}\right)$ for previous $10 \mathrm{~d}$.

${ }^{\mathrm{y}} \mathrm{b}$ soil $=$ Mean daytime soil temperature ${ }^{\circ} \mathrm{C}$ ) for previous $10 \mathrm{~d}$.

winds in exposed areas exceeded $9 \mathrm{~m} \cdot \mathrm{s}^{-1}$ for $\approx 3$ h during the night of July 8 but were only $\approx 3$ $\mathrm{m} \cdot \mathrm{s}^{-1}$ in sheltered areas. Exposed plants were wind stressed by the bending, shaking, and twisting of the vines, and all exposed plants were blown to one side of the beds. The roots of some plants were almost pulled out of the soil (Fig. 1). In sheltered areas, little or no wind damage was apparent.

Sheltered plants were taller and had longer vines than those from exposed plots (Table 3 ). Leaf area and dry-matter accumulations of sheltered plants were significantly greater than those of exposed plants on most sampling dates (Table 3). The shoot relative growth rates of sheltered plants were greater than those of exposed plants at early growth stages, but differences were not significant at later times during both years (Table 3 ).

The greater dry-matter production of sheltered plants was related to the greater accumulations of daytime air temperatures (Fig. 2). A positive relationship between mean daytime air temperature and shoot relative growth rate was found during early growth stages (the first $30 \mathrm{~d}$ after transplanting) in both sheltered and exposed areas (Table 4), but no clear relationship was detected later in the growing season.
Shoot relative growth rate and daytime soil temperatures were positively correlated during the early growing season each year in both sheltered and exposed areas (Table 4), as shown by Dunlap (1986). Although the relationship between shoot relative growth rate and both soil and air temperature accumulated for periods of 3,10,14, and $30 \mathrm{~d}$ and day/night data prior to sampling was analyzed, the best fit (highest $R^{2}$ ) was with accumulated average hourly daytime air temperatures for $10 \mathrm{~d}$ prior to sampling.

Yield. Differences in total yields between sheltered and exposed areas were nonsignificant during the early harvests in 1992; however, the total yields from exposed plants were greater later in the 1992 season (Fig. 3A). This may be due, in part, to an attempt to tag the first early female flowers at anthesis, which resulted in fruit abortion. Since female flowers developed earlier in the sheltered plots, this resulted in more fruit loss in the sheltered areas than in the exposed areas. In 1993, when no flowers were tagged, the earlier and more rapid development of sheltered plants significantly increased the total yields from the early harvests over those of the exposed plants (Fig. 3B). However, when all harvests within sheltered or exposed plots were combined, the analysis of variance indicated no significant increase in the total yields in either year $(P=$ 0.295 in 1992 and $P=0.168$ in 1993). The early marketable yield was significantly greater from sheltered areas in $1993(P=0.008$, Fig. 4B) but not in 1992 ( $P=0.175$, Fig. 4A). The air temperatures early in the season were lower in 1992 than in 1993, especially at night in the sheltered areas, and sheltered plants probably experienced more chilling stress than did the exposed plants. For example, on the night of 28 May 1992, air temperature dropped to a low of $1.2{ }^{\circ} \mathrm{C}$ in sheltered areas and $2.5^{\circ} \mathrm{C}$ in exposed areas. During this time, air temperatures were $<16{ }^{\circ} \mathrm{C}$, the minimum for muskmelon germination (Knott et al., 1988), for 39 consecutive hours in each area. Conversely, during the first 3 weeks after transplanting in 1993, the lowest air temperature was 6.4 and $7.7^{\circ} \mathrm{C}$ for the sheltered and exposed areas, respectively. The average daily air temperature during the first 3 weeks after transplanting was $\angle 16^{\circ} \mathrm{C}$ eight times for both sheltered and exposed plots in 1992. In 1993, this occurred five times in sheltered plots and four times in exposed plots.

\section{Conclusions}

Shelterbelts provided improved growing conditions for muskmelon transplants. The duration of wind speeds $>4 \mathrm{~m} \cdot \mathrm{s}^{-1}$ was reduced between $47 \%$ and $56 \%$ with a reduction in direct wind damage to the plants during the growing season. Air temperature was higher in sheltered areas during the daytime and lower at night, especially early in the growing season. Also, soil temperature in the sheltered areas was usually higher than in the exposed areas. These changes in air temperature appeared to be a function of the exposed wind velocity and direction, as well as the radiation 


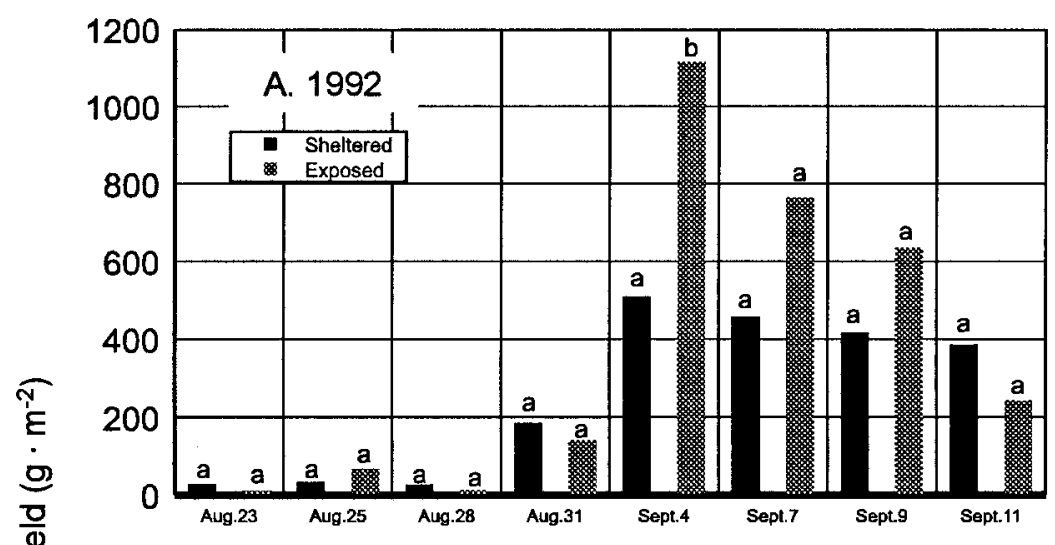

load (sunny vs. cloudy day), and advective or nonadvective conditions.

Sheltered plants developed earlier and grew more rapidly. They were taller and had longer vines than plants exposed to wind stress. The earlier development and faster growth were related to wind speed reduction, accumulation of daytime air heat units, and higher soil temperature in the sheltered areas. Although differences in total yields between sheltered and exposed muskmelon crops were nonsignificant, the earlier maturity and potentially greater marketable yield in a wind-sheltered area could provide both earlier and greater dollar returns to the grower.

\section{Literature Cited}

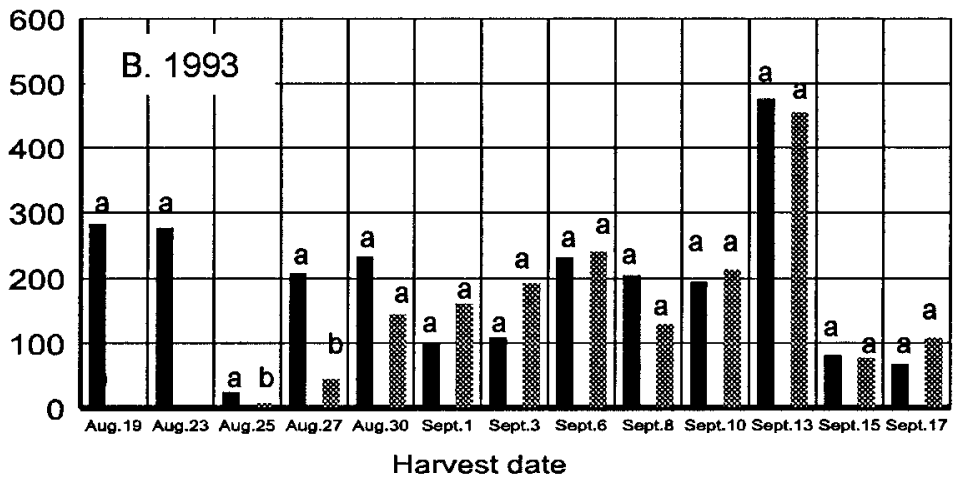

Fig. 3. Effects of shelters on total fruit yields for eight harvests in 1992 (A) and 13 harvests in 1993 (B). Mean separation within sample dates by ANOVA at $P \leq 0.05$.



Fig. 4. Effects of shelters on marketable yields for sheltered and exposed areas for eight harvests in 1992 and 13 harvests in 1993. Mean separation within sample dates by ANOVA at $P \leq 0.05$.

ase, J.K. and F.H. Siddoway. 1974. Tall wheatgrass barriers and winter wheat response. Agr. Meteorol. 12:321-338.

Bagley, W.T. and F.A. Gowen. 1960. Growth and fruiting of tomatoes and snap beans in the shelter area of a windbreak. Proc. Fifth World For. Conf. 3:1667-1671.

Baldwin, C.S. 1988. The influence of field windbreaks on vegetable and specialty crops. Agr., Ecosystems and Environ. 22/23:191-203.

Barker, G.L., J.L. Hatfield, and D.F. Wanjura. 1989. Influence of wind on cotton growth and yield. Trans. Amer. Soc. Agr. Eng. 32:97-104.

Black, A.L. and J.K. Aase. 1988. The use of perennial herbaceous barriers for water conservation and the protection of soils and crops. Agr., Ecosystems and Environ. 22/23:135-148.

Brandle, J.R., B.B. Johnson, and D.D. Dearmont. 1984. Windbreak economics: The case of winter wheat production in eastern Nebraska. J. Soil Water Conserv. 39:339-343.

Dunlap, J.R. 1986. Influence of soil temperature on the early growth of three muskmelon cultivars. Scientia Hort. 29:221-228.

Frank, A.B., D.G. Harris, and W.O. Willis.1974. Windbreak influence on water relations, growth, and yield of soybeans. Crop Sci. 14:761-765.

Grace, J. 1977. Plant response to wind. Academic, London.

Harrison, D.J. and J.R. Chrimes. 1988. The effect of shelter on the yield, quality and value of runner beans. Res. Dev. Agr. 5:53-58.

Knott, J.E, O.S. Lorenz, and D.N. Maynard.1988. Handbook for vegetable growers. Wiley, New York.

Kort, J. 1988. Benefits of windbreaks to field and forage crops. Agr., Ecosystems and Environ. 22/ 23:165-190.

Lawson, M.P., F.D. Kenneth, and R.E. Neild. 1977. Climatic atlas of Nebraska. Univ. of Nebraska Press, Lincoln.

Maki, T. 1990. Preventing of wind damage and using of climatic resources. Farming Japan 24:610.

Marshall, J.K. 1967. The effects of shelter on the productivity of grasslands and field crops. Field Crop Abstr.24:1-14.

Ogbuehi, S.N. and J.R. Brandle. 1982. Influence of windbreaks-shelter on soybean growth, canopy structure, and light relations. Crop Sci. 22:269273.

Rosenberg, N.J., B.L. Blad, and S.B. Verma. 1983. Microclimate: The biological environment. Wiley, New York.

SAS Institute Inc. 1985. SAS user's guide: Statistics. SAS Inst., Cary, N.C.

Wei, L., A. Jiang, and Y. Zhang. 1987. On the effective protecting distance of shelterbelts. Kexue Tongbao (Sci. Rpt.) China 32:605-609. 